\title{
TRANSLATION, ADAPTATION, VALIDITY AND RELIABILITY OF THE SENSE-MAKING SCALE: A CROSS-CULTURAL EVIDENCE FROM INDIA, MALAYSIA, ROMANIA AND TURKEY ${ }^{1}$
}

\author{
ANLAMLANDIRMA ÖLÇEĞİNIN ÇEVİRİSİ, UYARLAMASI, GEÇERLİLİK VE \\ GÜVENILIRLİĞİ: HINDISTAN, MALEZYA, ROMANYA VE TÜRKIYYE'DEN \\ KÜLTÜRLERARASI BİR KANIT
}

\author{
Türker TUĞSAL ${ }^{2}$
}

\begin{abstract}
The main object of this research is translation, adaptation, validity and reliability of the Sense-Making Scale's Turkish version to English so as to be used in cross-cultural researches. Even though there are extensive studies which have been carried out on sense-making, any sense-making scale or questionnaire in the existing literature is not consistent and there is a gap that should be filled. The contribution of this research is to redound a sensemaking measurement tool in English. Firstly, the related literature is reiterated and a pilot study of translated scale is applied for validity and reliablity. After reliability is assured, the surveys are sent to 600 academicians in India, Malaysia, Romania and Turkey and 466 of the data are valid. The data fit to normal distribution. Cronbach's Alpha value is found reliable (0.763) and the variability of the scale is $61.257 \%$. The first possible explanation for these results is being the first measurement tool about sense-making in English. The second implication of the study is; sense-making of signs such as action, discourse, diagnosis, facts orelse events may let people prevent from adverse, negative and unfavourable incidents such as accidents, chaoses or crises which may occur in times to come.
\end{abstract}

Keywords: Sense-Making Scale, Scale Translation and Adaptation, Cross-Cultural Evidence, India, Malaysia, Romania and Turkey.

\section{$\ddot{O} \mathbf{z}$}

Bu araştırmanın temel amacı, Anlamlandırma Ölçeğinin Türkçe versiyonunun kültürlerarası araştırmalarda kullanılmak üzere geçerliliği, güvenirliği sağlanarak İngilizce versiyona uyarlanabilmesidir. Anlamlandırma üzerine yapılmış kapsamlı çalışmalar olmasına rağmen, İngilizce literatürde herhangi bir anlamlandırma ölçeği veya anketi bulunmamaktadır ve literatürde doldurulması gereken bir boşluk bulunmaktadır. Bu araştırmanın literatüre katkısı, İngilizce anlamlandırma ölçeği sunmaktır. İlk olarak, geçerlik ve güvenilirlik için çevirisi yapılan ölçeğin 66 akademisyenden oluşan katılımcıyla pilot çalışması uygulanmıştır. Geçerlik ve güvenilirlik sağlandıktan sonra Hindistan, Malezya, Romanya ve Türkiye'deki 600 akademisyene çevrimiçi anket e-posta ile gönderilmiştir ve 466 geçerli veri elde edilmiştir. Veriler normal dağılıma uymaktadır. Cronbach Alfa değeri güvenilir bulunmuştur (0.763) ve ölçeğin değişkenliği \%61.257'dir. Bu sonuçlara göre; İngilizce olarak kullanılabilecek anlamlandırma ile ilgili ilk ölçüm aracı sağlanmaktadır. Çalışmanın ikinci önemi; eylem, söylem, tanı, gerçekler ya da diğer olaylar gibi işaretlerin anlamlandırılması; insanların gelecek zamanlarda meydana gelebilecek kaza, kaos ya da kriz gibi olumsuz ve istenmeyen olayları önlemesine izin verebilir.

Anahtar Kelimeler: Anlamlandırma Ölçeği Uyarlaması, Hindistan, Malezya, Romanya ve Türkiye.

\footnotetext{
${ }^{1}$ The survey permission was evaluated by the Publication Ethics Committee for the Social and Human Sciences of Beykent University and approved on 10/02/2019.

${ }^{2}$ Assist. Prof. Dr., Beykent University, Faculty of Economics and Administrative Sciences, t.turker@gmail, Orcid: https://orcid.org/ 0000-0002-7585-4989.
} 


\section{Introduction}

Sense-making concept and the related studies are generally searched in organizational behavior field related with organizational communication and crisis communication. It is seen that various organizational issues related to the concept of sense-making are examined. In the current literature, including in different disciplines; integration of cultural sense-making (Dyer, 2017), the process of sense-making for adaptation of organizational settings (Ito and Inohara, 2015), sense-making in international affairs (Jakobsen, Worm \& Li, 2018), sensemaking in developing markets (Kharchenkova, 2018), cognition, action and outputs (Mattsson, Corsaro \& Ramos, 2015), strategic management accounting and sense-making (Tillmann \& Goddard, 2008), financial crises and sense-making (Tuğsal, 2015), sense-making in business life (Tuğsal, 2016), crisis communication and sense-making (Xu, 2018). On the contrary, although there is a lot of research about sense-making in the existing literature; there is not any sense-making scale in English in social sciences and there is a significant gap to be filled. In this context, the attempt of this research is translation and adaptation of Turkish version of the Sense-Making Scale.

In the existing literature there is a lot of research about sense-making. One exception is the study of Pakenham (2007) in medical science related to making sense of MS (Multiple Sclerosis) which is applied to determine the links of sense-making and adjustment outcomes. However it isn't related with organizational behavior and the sample consists of MS people. It is seen that there has been only one sense-making scale in Turkish that has been developed (Tuğsal, 2019). The lack of a validated and reliable sense-making measurement tool in English that can be used in different cultures, besides the necessity of cross-cultural translation and adaptation makes this research significant.

The term "scale" is defined by DeVellis (2012) to refer measuring instruments consisting of expressions aiming to measure the levels of cases with theoretical presence but not directly observed. Scales can be developed in two ways. The first way is to prepare a scale for self-culture. The second way is to adapt a measurement instrument developed in a foreign culture to native culture. One of the most important reasons for the need to conduct an international comparative scale development attempt is to consider what it means to prevailingly manage institutions in different cultures. Due to the fact that there have been cultural differences; translation of a scale from a foreign language may cause many possible faults related to reliability and validity of scale adaptation.

In the literature, it is seen that scales are generally brought to cultures as a result of adaptation. In this context, the main goal of this study and its contribution to the literature is to adapt Tuğsal's (2019) Sense-Making Scale. However, there is a specific methodology for scale development. Scale development studies are usually carried out by experimental or theoretical processes. Yurdugül (2005) describes the stages of the experimental process commonly used in scale development studies; determination of the property to be measured, obtaining candidate scale, determination of literature and scale items, experimenting with appropriate sample and obtaining experimental form as a result of factor analysis.

The main purpose of scale adaptation is to create a viable type of the data which have been equivalent to the original version of the measurement instrument in different cultures. It is commonly been assumed that (Beaton, Bombardier, Guillemin \& Ferraz, 2000; Epstein et al. 2015:360-369; Guillemin, Bombardier \& Beaton, 1993) the back translation is the technique which is produced from the target language to original language. According to recent researches (Caminiti et al., 2010; Gonc, alves et al., 2010) although the back translation process is time-consuming and expensive, it is mostly considered that it gives a satisfactory result and the best practice. 
The S-MS was developed to measure the sense-making. It consists of 22 items in five components. Two independent professional committees were comprised of two billingual translators and one expert in organizational behavior theory and methodology. All professionals were able to recommend changes freely if they thought improvements in translation quality. Two translators and committee members were informed in advance about the instructions.

The generalizability of the findings in this research are potentially limited by generating a single translation method. To overcome this limitation, different translation techniques may have been applied, besides the number of committee members may have been increased; but these additions would have been consuming more time, cost and resource. Backward translation was used as the source to confirm which technique (forward, committee or both of them) was better for the translation (Epstein et al., 2015).

\section{Theoretical Background of Sense-Making Concept and Review of the Literature}

Meaning can be defined as the understanding from a word, a behavior or a fact (www.tdk.gov.tr). In order to make sense in relation to the concept of meaning; cases, signs, expressions or behaviors are needed. In this context, sense-making can be defined as the process of perceiving, understanding, analyzing, interpreting and making sense of words, behaviors, signs, symbols, diagnoses, expressions, observations or symptoms.

Maitlis \& Christianson (2014) hold the view that sense-making is the process of interpreting clues. According to Gross (2010), sense-making is expressed as situational awareness as a result of impressions entering the mind from the external environment. Dougherty \& Drumheller (2006) argue that if there is a shock to the system or a deterioration in the system, it will be meaningful. Emotions that allow individuals to make sense provide this deterioration, but individuals tend to catch clues with emotional coincidences that focus on rational business practices.

The Sense-Making Theory is referred to Karl Weick; however, it is still an area of development in the literature. In the 1970s and 1980s, sense-making was first developed as an approach to information needs and communicative research. The Sense-Making Theory remains a topic of interest to researchers and theorists, and different approaches to theory are proposed. One of the most important of these is Karl Weick's Cognitive Psychology Model. Weick (1988) states that enacting involves both a process, a product and an environment. The enacted environment defines residues from the change generated by the enacting. The product of the enacting is expressed as a regular, material and social structure that causes comments.

The second important approach is Louis' Organizational Entry Model. Louis, on the other hand, evaluated the meaning from a micro-cognitive perspective and defines the three sense-making processes as perception, diagnosis and interpretation. The first process is the conceptualization of perception signs. Signs types are listed as changes, contradictions and surprises. Change is defined as objective differences between the old situation and the new one. On the contrary, contrasts are defined as subjective differences between the old situation and the new one. Contrasts are not known in advance. The surprises are defined as the differences between the individual's expectations and the actual situation. The main contribution of Louis' model is that surprises trigger the process of sense-making (Smerek, 2009).

When changes, contradictions and surprises are examined as a process of identification and interpretation; these cognitive events are defined as meaning. According to a definition provided by Smerek (2009) meaning is the development of an explanation of the questions 
that individuals cause and what they mean. There are various inputs that shape these explanations and meanings based on change, contrasts and surprises. These entries are; past experiences, personal predispositions, local comments and orders, information and comments from other individuals. According to the existing literature, the researches on Sense-Making Theory are introduced in Table 1 .

Table 1: Existing Researches on Sense-Making Theory

\begin{tabular}{llll}
\hline \multicolumn{1}{c}{ Researchers } & $\begin{array}{c}\text { Object of the } \\
\text { research }\end{array}$ & $\begin{array}{c}\text { Method/ } \\
\text { Approach }\end{array}$ & \multicolumn{1}{c}{ Findings and Results } \\
\hline $\begin{array}{l}\text { Foldy, } \\
\text { Goldman \& } \\
\text { Ospina (2008) }\end{array}$ & $\begin{array}{l}\text { Conscious change in } \\
\text { organizations }\end{array}$ & $\begin{array}{l}\text { Induction and } \\
\text { deduction }\end{array}$ & $\begin{array}{l}\text { A theoretical and methodological approach to } \\
\text { meaningful activity directed by individuals and } \\
\text { groups was conducted. }\end{array}$ \\
$\begin{array}{l}\text { Hermann \& } \\
\begin{array}{l}\text { Dayton } \\
(2008)\end{array}\end{array}$ & $\begin{array}{l}\text { Politicians' sense- } \\
\text { making styles in } 77 \\
\text { crisis events }\end{array}$ & $\begin{array}{l}\text { Observation and } \\
\text { literature review }\end{array}$ & $\begin{array}{l}\text { It was concluded that the structure of the } \\
\text { decision unit, the best action plan and the } \\
\text { perceptions and thoughts about who would do } \\
\text { this would change in the strategies that take time } \\
\text { to react. }\end{array}$
\end{tabular}

$\begin{array}{lll}\text { Tillmann \& } & \begin{array}{l}\text { Sense-making in } \\ \text { strategy formation } \\ \text { Goddard (2008) }\end{array} & \begin{array}{l}\text { Observation and } \\ \text { management } \\ \text { accountants }\end{array} \\ & \begin{array}{l}\text { In the field of } \\ \text { cognitive and } \\ \text { meaningfulness in } \\ \text { business networks, }\end{array} & \\ \text { Henneberg, } & \text { eight of the existing } \\ \text { Naude \& } & \text { Literature review } \\ \text { Mouzas (2010) } & \begin{array}{l}\text { researches in the } \\ \text { literature have been } \\ \text { used as experimental } \\ \text { studies. }\end{array} & \\ & \end{array}$

According to the findings the ultimate goal of decision-makers in terms of strategy formulation was meaningful communication.

It was stated that the meaning skills of the individual are based on role, learning capacity and cognitive structure. It is stated that there is no linear relationship between the size and level

Weinberg,

Wiesnar \&

Fukawa-

Connelly

(2014)

To define the various ways in which students sense-make

Interview

in mathematics.

\section{Carr, Gilbride Sense-making}

\& James (2016) capabilities

Hahn et al.

Hughes et al.

\section{Student sense-} making on physics homework

Critical incident technique of business network in organizations.

Regarding to the results it has been observed that interpretation affects the note-taking practices of students who deal with content-oriented interpretation, communication-oriented interpretation and placement-oriented interpretation.

The analysis of sense-making capabilities indicate differences in sensitivity and interpretation.

Researchers state that the most common sensemaking strategy was to check the units or dimensions of an answer and secondly to substitute the fundamental dimensions of quantities.

frequency analysis

Narrative

interviews

and cross-case thematic analysis

Schiavio \& De Participatory senseJaegher making in musical activity

Stieglitz et al. Sense-making in (2017) social media
Phenomenological and enactive perspective

Social network case analysis and sentiment analysis
The process of sense-making was not able to solve all problems but let participants to navigate the changes in their worldview.

According to the results enactive-friendly approaches provide a fertile ground for the study of cognition.

Findings show that there are differences in the communication structure of extreme events. 


\begin{tabular}{|c|c|c|c|}
\hline $\begin{array}{l}\text { Abbas et al. } \\
(2018)\end{array}$ & $\begin{array}{l}\text { Sense-making in } \\
\text { social media }\end{array}$ & $\begin{array}{l}\text { Text analytics and } \\
\text { coherence analysis }\end{array}$ & $\begin{array}{l}\text { The results indicate significant implications for } \\
\text { sense-making. }\end{array}$ \\
\hline Cerulo (2018) & $\begin{array}{l}\text { Sense-making scents } \\
\text { and meaning } \\
\text { attribution }\end{array}$ & Focus group & $\begin{array}{l}\text { The author explores sense-making and meaning } \\
\text { attribution and emphasizes that sense-making } \\
\text { varies by culture. }\end{array}$ \\
\hline $\begin{array}{l}\text { Cantarero et al. } \\
(2019)\end{array}$ & $\begin{array}{l}\text { Necessity for sense- } \\
\text { making }\end{array}$ & $\begin{array}{l}\text { Correlation } \\
\text { analysis }\end{array}$ & $\begin{array}{l}\text { Findings demonstrate that need for sense-making } \\
\text { has positive correlation with personality traits } \\
\text { and people's identity. }\end{array}$ \\
\hline $\begin{array}{l}\text { Cooper, } \\
\text { Ezzamel \& } \\
\text { Robson (2019) }\end{array}$ & $\begin{array}{l}\text { Multiple } \\
\text { performance } \\
\text { measurement } \\
\text { systems and sense- } \\
\text { making }\end{array}$ & $\begin{array}{l}\text { Qualitative and } \\
\text { interpretive } \\
\text { analysis }\end{array}$ & $\begin{array}{l}\text { Results emphasize that social skills in sense- } \\
\text { making allows continuity and absence of conflict } \\
\text { in organizations. }\end{array}$ \\
\hline $\begin{array}{l}\text { Haverly et al. } \\
(2020)\end{array}$ & $\begin{array}{l}\text { Investigating sense- } \\
\text { making moments }\end{array}$ & $\begin{array}{l}\text { Qualitative case } \\
\text { study }\end{array}$ & $\begin{array}{l}\text { Results suggest that novices may benefit from } \\
\text { students' sense-making. }\end{array}$ \\
\hline $\begin{array}{l}\text { Henneberg, } \\
\text { Naude \& } \\
\text { Mouzas (2010) }\end{array}$ & $\begin{array}{l}\text { In the field of } \\
\text { cognitive and } \\
\text { meaningfulness in } \\
\text { business networks, } \\
\text { eight of the existing } \\
\text { researches in the } \\
\text { literature have been } \\
\text { used as experimental } \\
\text { studies. }\end{array}$ & Literature review & $\begin{array}{l}\text { It was stated that the meaning skills of the } \\
\text { individual are based on role, learning capacity } \\
\text { and cognitive structure. It is stated that there is } \\
\text { no linear relationship between the size and level } \\
\text { of business network in organizations. }\end{array}$ \\
\hline
\end{tabular}

\subsection{Methodological Issues in Translation and Adaptation Process}

Adapting a scale from another culture may be a problem because a concept or expression may have an obvious meaning in a different cultural climate, even no meaning at all.

A significant distinction has to be made between translation, adaptation and crosscultural verification. Translation can be defined as the process of producing a document from a target language source. Adaptation, on the other hand, can be explained as the determination of the differences between source and target culture to maintain meaning equivalence. By doing cross-cultural verification, it aims to ensure that the new survey functions as intended and has the same features and functions as the original scale (Mokkink et al., 2010:737-745).

The translation, adaptation and validation of measurement tools or scales can take a lot of time for cross-cultural research. Therefore, cautious planning and particular methodological techniques are required to obtain a reliable and valid measurement tool. Intercultural and multinational researches are needed due to the increase in various populations worldwide. It has commonly been pointed out (Beaton, Bombardier, Guillemin \& Ferraz, 2000; Beaton, Bombardier, Guillemin \& Ferraz, 2002; Sousa, Zauszniewski, Mendes $\&$ Zanetti, 2005) that researchers should have access to cross-validated, reliable and valid tools or measures across the population or various cultural segments in other languages.

According to Malhotra, Agarwal \& Peterson (1996) translating the certain words, expressions or phrases directly may be inaccurate. Translation errors can be detected in backtranslation. Even if the questionnaire expressions are the same, different scale formats may not be compared. Therefore, in this research the format of the survey is tried to be kept homogeneous. In Table 2, theoretical background of methodological issues in cross-cultural translation and adoptation process of scales and questionnaires is introduced. 
Table 2. Theoretical Background of Methodological Issues in Cross-Cultural Translation and Adoptation Process of Scales and Questionnaires

\begin{tabular}{|c|c|c|c|}
\hline Researchers & $\begin{array}{l}\text { Object of the } \\
\text { research }\end{array}$ & $\begin{array}{l}\text { Method/ } \\
\text { Approach }\end{array}$ & Findings and Results \\
\hline $\begin{array}{l}\text { Hagell et al. } \\
(2010)\end{array}$ & $\begin{array}{l}\text { Method of } \\
\text { questionnaire } \\
\text { translation }\end{array}$ & $\begin{array}{l}\mathrm{DP}, \mathrm{FB} \text { and } \mathrm{BW} \\
\text { translation }\end{array}$ & $\begin{array}{l}\text { It was found that there was no obvious difference } \\
\text { between translation types. }\end{array}$ \\
\hline $\begin{array}{l}\text { Chen \& Boore } \\
(2009)\end{array}$ & $\begin{array}{l}\text { Methodological } \\
\text { review of } \\
\text { translation }\end{array}$ & Review & $\begin{array}{l}\text { Researchers recommended that translator's background } \\
\text { is a priority. }\end{array}$ \\
\hline $\begin{array}{l}\text { Maneesriwongu } \\
1 \& \\
\text { Dixon (2004) }\end{array}$ & $\begin{array}{l}\text { Translation } \\
\text { process }\end{array}$ & Review & $\begin{array}{l}\text { Regarding to the studies reviewed, there is no } \\
\text { consensus on translation technique. }\end{array}$ \\
\hline $\begin{array}{l}\text { Sousa \& } \\
\text { Rojjanasrirat } \\
(2011)\end{array}$ & $\begin{array}{l}\text { Translation and } \\
\text { adaptation } \\
\text { process of scales }\end{array}$ & Review & $\begin{array}{l}\text { Translation and validation processes require time and } \\
\text { financial issues. }\end{array}$ \\
\hline $\begin{array}{l}\text { Malhotra, } \\
\text { Agarwal \& } \\
\text { Peterson } \\
(1996)\end{array}$ & $\begin{array}{l}\text { Methodological } \\
\text { issues }\end{array}$ & Review & $\begin{array}{l}\text { Establishing the equivalence of questionnaire from } \\
\text { different countries is critical. }\end{array}$ \\
\hline $\begin{array}{l}\text { Epstein et al. } \\
(2015)\end{array}$ & $\begin{array}{l}\text { Adaptation of } \\
\text { questionnaire }\end{array}$ & $\begin{array}{l}\text { Experimental } \\
\text { study }\end{array}$ & $\begin{array}{l}\text { Authors recommended that using cross-cultural } \\
\text { methods need in this field. }\end{array}$ \\
\hline $\begin{array}{l}\text { Yasir Arafat et } \\
\text { al. } \\
(2016)\end{array}$ & $\begin{array}{l}\text { Adaptation of } \\
\text { instruments }\end{array}$ & $\begin{array}{l}\text { Methodological } \\
\text { review }\end{array}$ & $\begin{array}{l}\text { Regarding to the sampling technique there has been } \\
\text { variation. While adapting scales, cultural and linguistic } \\
\text { issues of translation } \\
\text { have to be considered. }\end{array}$ \\
\hline Sekaran (1983) & $\begin{array}{l}\text { Methodological } \\
\text { issues }\end{array}$ & Review & $\begin{array}{l}\text { The researcher stated that there are many comparable } \\
\text { studies in different countries therefore, this situation is } \\
\text { not critical. }\end{array}$ \\
\hline $\begin{array}{l}\text { Nasif et al. } \\
(1991)\end{array}$ & $\begin{array}{l}\text { Methodological } \\
\text { problems }\end{array}$ & Review & $\begin{array}{l}\text { According to the authors the main methodological } \\
\text { problmes are criterion, simplicity, sampling and } \\
\text { generalizibility. }\end{array}$ \\
\hline $\begin{array}{l}\text { Epstein, Santo } \\
\text { \& Guillemin } \\
(2015)\end{array}$ & $\begin{array}{l}\text { Adaptation of } \\
\text { questionnaire }\end{array}$ & Review & $\begin{array}{l}\text { Adaptation in a different culture may cause a problem } \\
\text { because of meaning differences. }\end{array}$ \\
\hline $\begin{array}{l}\text { Ortiz-Gutiérrez } \\
\text { \& Cruz-Avelar } \\
(2018)\end{array}$ & $\begin{array}{l}\text { Translation of } \\
\text { adaptation } \\
\text { process }\end{array}$ & Review & $\begin{array}{l}\text { There is a need to adapt culturally different scales } \\
\text { before using them. }\end{array}$ \\
\hline
\end{tabular}

Hagell et al. (2010) states that DP approach has advantages over FB translation. By contrast, Perneger, Leplege \& Etter (1999) and da Mota Falcao, Ciconelli \& Ferraz (2003) claim that one translation method does not have a distinct psychometric advantage over another. Acquadro et al. (2008) states that one of the most preferred methods for translation is backward and forward translation. Likewise, Bonomi et al. (1996); Beaton et al. (2000); Maneesriwongul \& Dixon (2004) and Wild et al. (2005) propose the FB translation method. Therefore, in this research Tuğsal's (2019) the original Turkish version of the Sense-Making Scale (S-MS) was adapted to English using the forward-backward (FB) translation approach. Since it is necessary to study in countries that are culturally different from populations; in order to use measurement and evaluation tools in new contexts, there is a need to adapt the Sense-Making Scale (S-MS) to English.

Ortiz-Gutiérrez and Cruz-Avelar (2018: 202-206) claim that the translator should be the native speaker of the source language and should have sufficient knowledge of the the new version of the target language. Therefore, Keiichiro (2001) \& Wu (2006) state that 
translator plays an important role in investigating the potential of translating the second language as close as possible to the original language through translation.

The difficulty is that the translation depends on both language and culture. Researchers aiming to translate as close as possible in structure and form. They translate into the original language, taking into account the cultural nuances involved in the use of translation (Cruz et al. 2000). Chen \& Boore (2009) also list factors affecting translation quality as translation, culture and language. Brislin (1970) hold the view that the most preferred and most recommended approach for translation studies is the translation method.

One major drawback might be to define the equivalence of terminology and conceptual meaning. Twinn (1998) and Esposito (2001) highlight that these interventions will be appropriate to ensure the reliability of qualitative study. On the other hand, since the meanings of component structures can change from one culture to another; Munet-Vilar'o \& Egan (1990) suggest that in the researches in which quantitative methods will be used, these measures should be translated into the language of culture examined.

Regarding the methods, Maneesriwongul \& Dixon (2004) reviewed forty-seven studies that included the translation of quantitative research tools. 38 of the 47 studies used forward and reverse translation. However, it has been stressed that there is no standard manual for instrument translation. The back translation approach also assures to accomplish conceptual equivalence. As a result, it is seen that there is not one perfect translation technique in all intercultural studies. Furthermore, consensus among researchers is required on how to ensure instrument translation in intercultural research.

\subsection{Translation and Adaptation Process of the Sense-Making Scale}

Translation and adaptation process of the Sense-Making Scale is illustrated in the Figure 1. The first step states the preliminary draft of the Sense-Making Scale verbatim in Turkish. After two independent translations to English, conceptual analysis was implemented by OB theorist, methodologist and bilingual translators. Then, expert committees evaluated Back Translation 1 and 2. Finally, expert committee of bilingual translators compare the conceptual results for translation and back translation. 


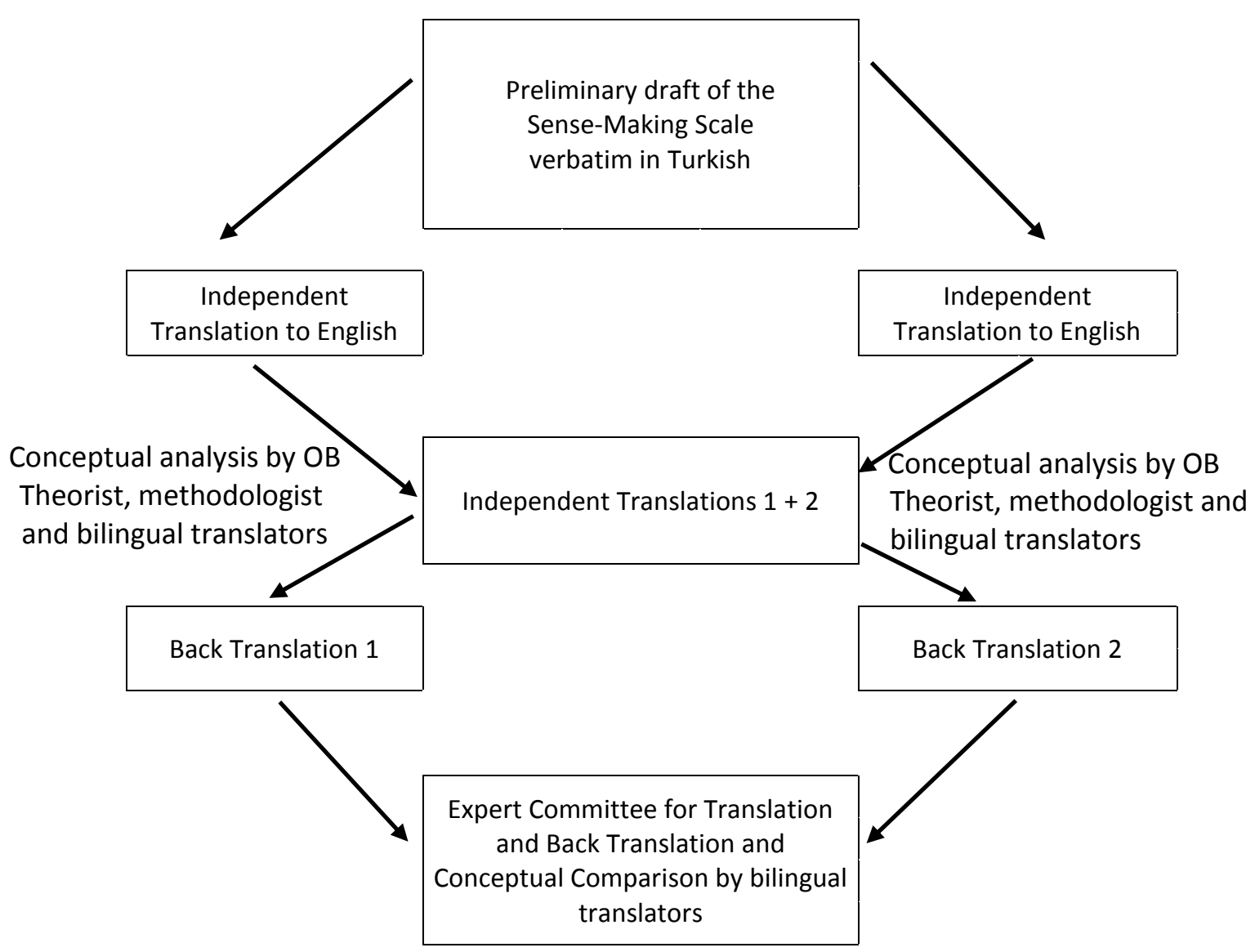

Figure 1. Translation and Adaptation Process of the Sense-Making Scale

\section{Materials and Methodological Approach}

The original Turkish version of the Sense-Making Scale (S-MS) (Anlamlandirma Ölçeği; Turkish version; Tuğsal, 2019) is produced by means of the FB translation approach. Then the pilot study was implemented with the scale in order to test reliability and structural validity. After pilot study, the scale was tested with a cross-cultural research so as to determine evidence whether it has cultural similarities or differences. With this cross-cultural evidence normality and linearity, reliability analysis, structural validity and factor loadings are calculated.

\subsection{Instrument Translation}

The Sense-Making Scale consists of 22 items. 5-point Likert type items have been used. The official Turkish version of The Sense-Making Scale is translated with FB translation model. The official Turkish version of the The Sense-Making Scale was translated into English and were combined into one by the author. Afterwards, it was back-translated into Turkish by another independent translator. Finally, this version was assessed by expert committee for translation, back translation and conceptual comparison whether English version was understood by bilingual translators. Participants found The Sense-Making Scale easy to understand. Since no changes were reported about The Sense-Making Scale, the final form was accepted.

\section{Translation Committee Members and Procedures}

The billingual assessors had access to both English Sense-Making Scale version as well as the original Turkish version of The Sense-Making Scale. All the billingual assessors were instructed to recommend their preference of wording of the statements with regard to convenience, easiness and uncertainty of the language. In order to perform test-retest analysis, 
the pilot study was conducted with 66 participants repeated the questionnaire containing scale items approximately 1 month apart (30 to 45 days) and the correlation between the two tests was well $(r=0.91)$. Quantitative analyses were conducted via online survey with 600 academics from Turkish, Romanian, Indian and Malaysian universities. All participants were selected randomly and provided online written informed consent. Afterwards, by using this valid and reliable scale, a cross-cultural research with 466 participants was implemented.

\subsection{Measurement and scaling}

Regarding equivalence in scales, Malhotra, Agarwal \& Peterson (1996) argue that it is important to determine the equivalence of scales used to acquire data from other cultures. Measurement tool equivalence is interpreted in the same way across cultures. The measurement equivalence measures the structure equally in intercultural data. It refers to translation or linguistic equivalence. In this way, the scales will be easily understood by researchers from different cultures and will have an equivalent meaning.

Bhalla \& Lin (1987) also reported that scalar equivalence examined the same consistency or structure. Authors state that they examined if the scores received from participants from other cultures have the same meaning. In this context, this research consists of different cultures -two countries from Europe (Romania and Turkey) and two countries from Asia (India and Malaysia) in order to be considered a measure of equivalence.

Paula, Haddad, Weiss, Dini \& Ferreira (2014) maintain that cultural adaptation reduces the cost and time spent on development and allows the previously widely used instrument to be used for intercultural comparisons. MacCallum, Widaman, Zhang \& Hong (1999) assert that samples in the range of 100-200 are acceptable with well- determined factors. On the EFA basis of the sample size estimate, it is also suggested that the sample size should vary between 100 and 250. Some authors use the Kaiser-Meyer-Olkin (KMO) sample proficiency test to ensure adequate sample size. Different authors (Arafat et al., 2016) receive different KMO values ranging from 0.50 to 0.60 as the proficiency level. Anthoine, Moret, Regnault, Sébille \& Hardouin (2014), Santos et al. (2015) and Williams, Onsman \& Brown (2010) imply that it is necessary to provide at least 100-250 subjects based on the EFA sample size estimation recommendations.

Some authors (Arafat, 2016; Leite et al. 2013; Müller, Kohlmann \& Wilke, 2015; Ola \& Igbokwe, 2011; Parsian \& Dunning, 2009; Riva et al., 2015; Trousselard et al., 2010) as routine part of EFA for statistical analysis, used the KMO sample adequacy during statistical analysis. The proficiency was interpreted differently among the authors whose KMO level was stated as 0.6 . Therefore, there have been differences according to the researchers in terms of sample size estimation, sampling technique and sample size estimation formula.

\subsection{Analysis and Findings of the Pilot Study}

In order to perform test-retest analysis, 66 participants repeated the questionnaire containing scale items approximately 1 month apart (30 to 45 days) and the correlation between the two tests was well $(\mathrm{r}=0.91)$. Afterwards, by using this valid and reliable scale, a cross-cultural research with 466 participants was implemented. Online survey The SenseMaking Scale data were analyzed seperately with respect to descriptive statistics. SarisBaglama et al. (2004) express that regarding to the data quality missing statement responses should be $<10 \%$. Nunnally \& Bernstein (1994) express that regarding to the internal consistency reliability Cronbach's alpha should be $>0.70$. Firstly, reliability analysis of the scale was made and then factor analysis was performed. As a result of the reliability analysis of the scale, it is seen that Cronbach's $\alpha$ value is high. Mean, standard deviation and variance values related to the scale are presented in Table 3. 
Table 3. Reliability Statistics of The Sense-Making Scale in Pilot Study

\begin{tabular}{lc}
\hline Cronbach's $\boldsymbol{\alpha}$ & .767 \\
Standardized Cronbach's $\boldsymbol{\alpha}$ & .778 \\
$\overline{\boldsymbol{x}}$ & 78.950 \\
Variance $\left(\boldsymbol{\sigma}^{2}\right)$ & 59.459 \\
SD $(\sigma)$ & 7.711 \\
\hline
\end{tabular}

As introduced in Table 4, the result of Keiser-Meyer-Olkin sampling adequacy (.726) and Bartlett's sphericity test $\left(X^{2}=749,210\right.$, which are prerequisites for factor analysis, appear to be statistically significant $(\mathrm{p}<0.001)$. As a result of the explanatory factor analysis of the Sense-Making Scale, it is observed that there are 4 factors with an Eigen value above 1. First factor explains sense-making with $16.301 \%$ variance, second factor explains with $16.182 \%$, the third one with $14.262 \%$ and fourth factor with $11.564 \%$. Four factors explain sensemaking cumulatively with $58.309 \%$ variance.

Table 4. Factor Analysis and Statistical Results Table of the Sense-Making Scale Pilot Study

\begin{tabular}{|c|c|c|c|}
\hline Factors & Factor Loadings & Variance $(\%)$ & Cumulative Variance (\%) \\
\hline \multicolumn{4}{|c|}{ Factor 1 (7 items) } \\
\hline Expression6 &, 752 & & \\
\hline Expression 9 & ,723 & & \\
\hline Expression1 & 698 & & \\
\hline Expression 3 & ,670 & 16.301 & 16.301 \\
\hline Expression 11 & ,634 & & \\
\hline Expression 20 &, 510 & & \\
\hline Expression 2 & ,497 & & \\
\hline \multicolumn{4}{|c|}{ Factor 2 (7 items) } \\
\hline Expression4 & ,731 & & \\
\hline Expression5 & ,713 & & \\
\hline Expression 17 & ,650 & & \\
\hline Expression 16 & 609 & 16.182 & 32.482 \\
\hline Expression 19 &, 533 & & \\
\hline Expression 18 &, 518 & & \\
\hline Expression 12 & ,473 & & \\
\hline \multicolumn{4}{|c|}{ Factor 3 (3 items) } \\
\hline Expression 22 & ,856 & & \\
\hline Expression 15 & ,786 & 14.262 & 46.745 \\
\hline Expression 14 & ,722 & & \\
\hline \multicolumn{4}{|c|}{ Factor 4 (3 items) } \\
\hline Expression 10 & ,790 & & \\
\hline Expression7 & ,705 & 11.564 & 58.309 \\
\hline \multirow[t]{5}{*}{ Expression8 } & ,587 & & \\
\hline & & Total variance $\sigma^{2}$ : & 58.309 \\
\hline & & Keiser-Meyer-Olkin: & .726 \\
\hline & & Bartlett $\chi^{2}$ : & 749.210 \\
\hline & & $\mathrm{p}:$ & .000 \\
\hline
\end{tabular}




\subsection{Cross-Cultural Research Findings}

At this section of the research the universe, sample size and participants, normality, reliability analysis, structural validity and explanatory analysis are introduced.

\subsubsection{The Universe, Sample Size and Participants of Cross-Cultural Research}

Due to the fact that cultural norms and values are placed in the aspect that organizations cultivate; culture is a significant factor in organizations (Lammers \& Hickson, 1979; Laurent, 1981). However, most of the cross-cultural researches are limited and only carried out in small number of areas. Several cross-cultural studies in the literature are of just two nations. In their pioneering investigation Nasif, Al-Daeaj, Ebrahimi \& Thibodeaux (1991: 79-91) emphasise that sampling topics reflect a critical problem in intercultural research. The number of countries that are generally involved in intercultural research is low. Often only two cultures are compared. In 57 studies examined by Nath (1968), 54 percent were observed to be composed of two country studies. However, this research consists of four countries namely India, Malaysia, Romania and Turkey. This research would have been far more useful and persuasive by consisting four cultures.

Academics in the countries India, Malaysia, Romania and Turkey consist of the universe. A total of 466 out of 600 academics responded to the online survey, of whom 466 (77.66\%) consented and 134 academics chose not to respond. 466 participants 145 of whom are Turkish, 134 of whom are Indian, 94 of whom are Malaysian, 93 of whom are Romanian. There is not any missing values to transform. Participant characteristics, frequancy and percentages are introduced in the Table 5. Regarding to the different money units and purchasing power of countries, monthly total income of participants was asked in USD so as to make more accurate and meaningful comparison with analysis of variance for group differences.

Table 5. Descriptive Statistics of the Sample

\begin{tabular}{|c|c|c|c|}
\hline$N=466$ & & $\mathbf{f}$ & $\%$ \\
\hline \multirow{2}{*}{ Gender } & Women & 231 & 49.6 \\
\hline & Men & 235 & 50.4 \\
\hline \multirow{4}{*}{ Age } & $18-29$ & 30 & 6.4 \\
\hline & $30-39$ & 224 & 48.1 \\
\hline & $440-49$ & 111 & 23.8 \\
\hline & 50 and above & 101 & 21.7 \\
\hline \multirow{4}{*}{ Country } & Turkey & 145 & 31.1 \\
\hline & Romania & 93 & 20.0 \\
\hline & $\overline{\text { India }}$ & 134 & 28.8 \\
\hline & Malaysia & 94 & 20.2 \\
\hline \multirow{2}{*}{ Marital Status } & Single & 124 & 26.6 \\
\hline & Married & 342 & 73.4 \\
\hline \multirow{5}{*}{ Monthly Total Income } & $0-400$ USD & 122 & 26.2 \\
\hline & 401-1,000USD & 286 & 61.4 \\
\hline & $\begin{array}{l}1,001-2,000 \mathrm{USD} \\
\end{array}$ & 29 & 6.2 \\
\hline & $\begin{array}{l}2,001-3,000 \text { USD } \\
\text {. }\end{array}$ & 16 & 3.4 \\
\hline & 3,001-4,000USD & 13 & 2.8 \\
\hline \multirow{4}{*}{ Work Experience } & $0-2$ & 67 & 14.4 \\
\hline & $3-6$ & 106 & 22.7 \\
\hline & $7-10$ & 79 & 17.0 \\
\hline & $11-15$ & 214 & 45.9 \\
\hline
\end{tabular}


Normal distributions among single variables are examined according to kurtosis and skewness values. While Örün, Orhan, Dönmez \& Kurt (2015) advocate that kurtosis and skewness should be amongst -1 and +1 ; Emhan, Mete \& Emhan (2012:77) and Karagöz (2016) state that the kurtosis and skewness amongst -2 and +2 are accepted as the criterion for compliance with normal distribution. In this research skewness and kurtosis variables differ between -1 and +1 . Therefore, the data can be accepted appropriate for normal distribution.

Table 6. Skewness and Kurtosis Statistics for Normal Distribution

\begin{tabular}{lcc}
\hline Variable & Skewness & Kurtosis \\
\hline Expression1 & -.950 & .883 \\
Expression2 & -.592 & -.314 \\
Expression3 & -.981 & .914 \\
Expression4 & -.429 & .069 \\
Expression5 & -.617 & .572 \\
Expression6 & .610 & .946 \\
Expression7 & -.997 & .612 \\
Expression8 & -.941 & .492 \\
Expression9 & .808 & .910 \\
Expression10 & -.194 & -.068 \\
Expression11 & -.960 & .928 \\
Expression12 & -.703 & .849 \\
Expression13 & .973 & .963 \\
Expression14 & -.697 & .226 \\
Expression15 & -.740 & .752 \\
Expression16 & -.963 & .923 \\
Expression17 & -.511 & .406 \\
Expression18 & -.967 & .747 \\
Expression19 & -.682 & .682 \\
Expression20 & .952 & .915 \\
Expression21 & .918 & .959 \\
Expression22 & -.642 & .607 \\
\hline
\end{tabular}

\subsubsection{Reliability Analysis}

It is seen that the identical measurement tools may have different reliability scores in different cultures. A practical approach is proposed by Parameswaran \& Yaprak (1987) to compare the reliability of cross-cultural measurements. So as to analyze the data obtained from the questionnaires during the scale development stage SPSS 20.0 statistical software is used. Firstly, the data are prepared for analysis, the missing data are checked and the reverse materials are coded. Then, the reliability analysis and the construct validity of the scale are tested.

Table 7. Reliability Statistics of The Sense-Making Scale in Cross-Cultural Study

\begin{tabular}{lc}
\hline Cronbach's $\boldsymbol{\alpha}$ & .763 \\
Standardized Cronbach's $\boldsymbol{\alpha}$ & .794 \\
$\overline{\boldsymbol{x}}$ & 78.978 \\
Variance $\left(\boldsymbol{\sigma}^{2}\right)$ & 57.156 \\
SD $(\sigma)$ & 7.5602 \\
\hline
\end{tabular}

The Cronbach's $\alpha$ value, which is calculated as 0.763 in the scale consisting of 22 items, shows that the scale has acceptable reliability. The arithmetic mean of the scale is 78.978; variance is calculated 57.156; the standard deviation was calculated as 7.5602.

\subsubsection{Structural Validity and Explanatory Factor Analysis}

Fidell \& Tabachnick (2014: 660-662) emphasize that there are two main types of factor analysis one of them is exploratory and the second one is confirmatory factor analysis. Exploratory factor analysis may describe and summarize data by classifying variables. Since a 
tool is provided for grouping variables, exploratory factor analysis is generally performed at the initial phases of researches. By contrast with, confirmatory factor analysis is a much more complicated approach used in the advanced phases of the research which is used to test a theory.

Regarding to the interpretation of factors; as a general rule, only variables with factor load of 0.32 and above are interpreted. The larger the loading, the more pure measure of the variable factor. In their comprehensive study of Comrey \& Lee (1992), the loadings on 0.71 indicate excellent, 0.63 indicate very good, 0.55 good, 0.45 and 0.32 indicate that the loading should be interpreted poorly. The choice of cutoff for the loading size to be interpreted is a subject that depends on the researchers' preference.

Regarding to the factorability of $\mathrm{R}$, numerous pairs may be significant if $\mathrm{R}$ is factorable (Fidell \& Tabachnick, 2014: 667). Kaiser's measure of sampling adequacy is a ratio. KMO sample adequacy and Barlett Sphericity test are required for the compliance of the data with the principal components analysis (Tuğsal, 2018). 0.60 and above values are required for better factor analysis (Fidell \& Tabachnick, 2014: 667). In order to make a more meaningful interpretation of the principal components analysis, multiple rotations are performed. Eigen values of the expressions are accepted as 1 in the determination of the components. After the analysis of the principal components, factor loadings are higher than 0.40 .

After reliability analysis, explanatory factor analysis is implemented to consider the construct validity. In the explanatory factor analysis, "Principal Component" is used as the factor acquisition method and varimax rotation method is preferred. The result of KeiserMeyer-Olkin sampling adequacy (0.881) and Bartlett's sphericity test $\left(X^{2}=4597.212\right.$; $\mathrm{p}<0.001$ ), which are prerequisites for factor analysis appear to be statistically significant. KMO sample adequacy condition and Barlett Sphericity test condition are provided for factor analysis $(\mathrm{p}<0.001)$.

Table 8. Factor Loadings and Total Variance Statistics of the Sense-Making Scale

\begin{tabular}{|c|c|c|c|}
\hline Factors & Factor Loadings & Variance $\sigma^{2}(\%)$ & Cumulative Variance (\%) \\
\hline \multicolumn{4}{|c|}{ Factor 1 (6 items) } \\
\hline Expression6 & .741 & \multirow{6}{*}{16.142} & \multirow{6}{*}{16.142} \\
\hline Expression1 & .712 & & \\
\hline Expression 3 & .654 & & \\
\hline Expression 9 & .634 & & \\
\hline Expression 11 & .624 & & \\
\hline Expression 13 & .510 & & \\
\hline \multicolumn{4}{|c|}{ Factor 2 (4 items) } \\
\hline Expression4 & .843 & \multirow{4}{*}{13.732} & \multirow{4}{*}{29.874} \\
\hline Expression5 & .735 & & \\
\hline Expression16 & .647 & & \\
\hline Expression17 & .595 & & \\
\hline \multicolumn{4}{|c|}{ Factor 3 (5 items) } \\
\hline Expression 22 & .727 & \multirow{4}{*}{12.092} & \multirow{4}{*}{41.966} \\
\hline Expression 15 & .542 & & \\
\hline Expression14 & .524 & & \\
\hline Expression 2 & .516 & & \\
\hline
\end{tabular}




\begin{tabular}{|c|c|c|c|c|}
\hline Expression 12 & .408 & & & \\
\hline Factor 4 (4 ite & & & & \\
\hline Expression19 & .724 & \multirow{4}{*}{9.874} & \multirow{4}{*}{51.841} & \\
\hline Expression 21 & .627 & & & \\
\hline Expression 20 & .503 & & & \\
\hline Expression18 & .432 & & & \\
\hline \multicolumn{5}{|c|}{$\begin{array}{l}\text { Factor } 5 \text { (3 items) } \\
\text { (a) }\end{array}$} \\
\hline Expression8 & .771 & \multirow{3}{*}{9.416} & \multirow{3}{*}{61.257} & \\
\hline Expression 7 & .740 & & & \\
\hline \multirow[t]{5}{*}{ Expression10 } & .561 & & & \\
\hline & & Total variance $\sigma^{2}$ : & & 61.257 \\
\hline & & Keiser-Meyer-Olkin: & & .881 \\
\hline & & Bartlett $\chi^{2}$ : & & 4597.212 \\
\hline & & $\mathrm{p}:$ & & .000 \\
\hline
\end{tabular}

According to the results of varimax rotation with Kaiser normalization, there is not any variables which are loaded below 0.40 . Statements 1, 3, 6, 9, 11 and 13 are loaded on the first factor. The statements 4, 5, 16 and 17 are loaded on the second factor. The statements 2, $12,14,15$ and 22 are in the third factor; $18,19,20$ and 21 are in the fourth factor and finally statements 7,8 and 10 are loaded on the fifth factor.

As a result of the explanatory factor analysis of the Sense-Making Scale, it is observed that there are 5 factors with an Eigen value of 1 and above. First factor explains sense-making with $16.142 \%$ variance, while second factor explains with $13.732 \%$, the third one with $12.092 \%$, fourth factor with $9.874 \%$ and fifth factor with 9.416 . Five factors explain sensemaking cumulatively with $61.257 \%$ variance.

As a result of the principal component analysis, 22 items explained the scale with 5 factors and $61.257 \%$ variance. The nomenclature of the factors is made by taking into account the Sense-Making Theory and scale items. In this context; considering that the scale can also be used in international researches, the English equivalents of the factors are named as; the first factor is causality, the second factor is signs, the third factor is inconsistency, the fourth factor is contradiction and the fifth factor is surprises. Cronbach's Alpha values obtained as a result of reliability analyzes of the subscales of each of the five factors were as follows; 0.824 for the causality subscale; 0.859 for the signs subscale; 0.659 for the contradiction subscale; 0.823 for the inconsistency subscale and 0.603 for the surprises subscale.

\subsubsection{Sense-Making Mean Differences Between Groups According to ANOVA and t-test analysis}

In order to compare mean differences of groups for sense-making, since test of homogeneity of variances is not significant ( $p>$.05) Tukey test is implemented. According to ANOVA analysis there is significant sense-making differences between groups of countries. Malaysian academics' sense-making level is -0.14819 unit less than Indians' sense-making level. Moreover; Malaysians' sense-making level is -0.15577 unit less than Turkish academics' sense-making level. On the contrary, there is no significant difference between Malaysians' sense-making level and Romanians' sense-making level. 
Table 9. Mean Differences of Groups for Sense-Making

\begin{tabular}{ccllrc}
\hline Dependent Variable & Country & Countries & Mean Difference & SE & p \\
\hline \multirow{3}{*}{ Sense-Making } & \multirow{3}{*}{ Malaysia } & India & -.14819 & .04550 & .007 \\
& & Turkey & -.15577 & .04478 & .003 \\
& & Romania & -.08341 & .04946 & .332 \\
\hline
\end{tabular}

On the other hand, according to ANOVA analysis there is not any significant sensemaking differences between groups of ages, work experience and monthly income levels of participants. Regarding to t-test analysis, variances are equal ( $p>.05)$. Hence, there is not any significant sense-making differences between women and men groups. Furthermore, there is not any significant sense-making differences between single and married groups according to t-test analysis.

\section{Discussion}

Although there are many studies in the literature on the Sense-Making Theory, the lack of a study on the Sense-Making Scale indicates an important gap that needs to be filled in the literature. The present study attempted to translate and adapt the Sense-Making Scale developed in Turkey to use in English for cross-cultural researches. Indian, Malaysian, Romanian and Turkish cultures might be relatively different. Hence, it is difficult to accomplish conceptual equivalence. So, admissibility to potential participants is more significant. The Sense-Making Scale in the study explains the components by making use of the Sense-Making Theory. By using these components, research can be done in different disciplines. Investigations can be made by using the Sense-Making Scale in the field of organizational behavior, political science, military, economics.

The second issue to discuss is that ANOVA analysis illustrates sense-making differences between groups of countries. Malaysian academics' sense-making level is 0.14819 unit less than Indians' sense-making level and -0.15577 unit less than Turkish academics' sense-making level. However, there is no significant difference between Malaysians' sense-making level and Romanians' sense-making level. Since, investigating the cultural differences is not this research's aim, further studies may deal with the cultural differences according to Hofstede's Culture Typology. The only important thing that should be emphasized here regarding to culture is that, sense-making levels may differ from culture to culture.

\subsection{Limitations of the Research}

The research has some limitations. In scale development studies, the scales can be prepared either for the researcher's own culture or a measuring instrument developed in a foreign culture can be adapted by translating it into the native language of the researcher. In this context, the first limitation of the research is the application of the research in our own culture; testing in different cultures is recommended and required. The second limitation is that the research is conducted on academics. Therefore, the scale developed for the first time has been applied to a particular participant in the education sector, necessitating its implementation in different sectors and different participants. However, the reliability and validity of the scale developed in our own culture should be tested in different cultures.

Third limitation of the research is associated with scaling. Sekaran (1983) emphasized in a cross-national study the nuances of scaling as important aspects of measurement. Barry (1969) expresses that a 7-point Likert type is better than a 4-point Likert type scale. However, scales have been mostly used 5-point Likert type in many fields. Therefore, in this research 5point Likert type scale is used so as to be used in further different researches. 
Considering the lack of suitable sampling frameworks, Malhotra, Agarwal \& Peterson (1996) claim that probability sampling techniques are rare in cross-cultural researches, although they are more appropriate. In this context, it is tried to be collected primary data in this research. Besides, Yu et al. (1993) contended that attitude measures such as Likert scales are also culturespecific. The last limitation is scale type impacts across countries. Therefore, greater attention has to be paid to decrease scale type effects across cultural differences. To overcome this problem, research sample consists of Western and Eastern countries. From Europe Turkey and Romania are chosen and from Asia India and Malaysia are chosen.

\subsection{Current Recommendations for Researchers and Practitioners}

The use of the Sense-Making Scale in behavioral sciences can also be useful, innovative, ground-breaking and influential in economics, political science, medical science and military. In the context of suggestions to practitioners in further researches; it is thought that it can be used to investigate the relationship between organizational silence, organizational revenge, dark leadership, intention to quit, organizational commitment, social support, organizational identification which may be related to sense-making in the field of organizational behavior.

It is thought that validity will increase as more intercultural quantitative studies are conducted. In addition, the development of local expressions, signs and concepts in various countries and cultures will contribute to the Sense-Making Scale. Response equivalence, especially in developing countries; issues such as status and other psychological issues are important for cross-cultural data collection. Regarding this matter, Sekaran (1983) argues that response equivalence can be achieved by applying uniform data collection procedures in all cultures. Not much time should pass between periods when data is collected from different countries. This will increase the comparability of data from different cultures within a given time frame. The data in this research have been collected between April 2019 and October 2019.

\section{Conclusion}

The main evidence of this research to the existing literature of organizational behavior and communication is to contribute an original Sense-Making Scale. Another contribution is that; interpretation of action, facts, sypmtoms, diagnosis and events as a sign may allow reducing uncertainties for the prediction of possible adverse incidents such as errors, accidents, chaos and crises. The third contribution of the research is to provide the use of the scale in other disciplines and to pave the way for the development of different sense-making scales. The fact that research is being conducted in many disciplines related to sense-making will increase the number and type of scales with the contribution of this research. Findings illustrate that reliability of the scale and factor structure is similar. Translation and adaptation is acceptable, therefore English version of the Sense-Making Scale is recommended to be used in different cultures.

\section{Supplementary material}

Anlamlandırma Ölçeği (Original Turkish version of the Sense-Making Scale) article can be found at http://busbed.bingol.edu.tr/tr/download/article-file/689705

\section{Acknowledgments}

The author would like to thank all participating academics and bilingual translators for their cooperation. 


\section{References}

Abbas, A., Zhou, Y., Deng, S., \& Zhang, P. (2018). Text analytics to support sense-making in social media: A language-action perspective. MIS Quarterly, 42(2), 1-38.

Acquadro, C., Conway, K., Hareendran, A., et al. (2008). Literature review of methods to translate health-related quality of life questionnaires for use in multinational clinical trials. Value Health, 11(3), 509-521.

Anthoine, E., Moret, L., Regnault, A., Sébille, V., Hardouin, J. B. (2014). Sample size used to validate a scale: A review of publications on newly-developed patient reported outcomes measures. Health and Quality of Life Outcomes, 176(12), 1-10.

Arafat, S. M. (2016). Psychometric validation of the Bangla version of the patient-doctor relationship questionnaire. Psychiatry Journal, 1-4.

Arafat, S. Y., Chowdhury, H. R., Qusar, M. S., \& Hafez, M. A. (2016). Cross cultural adaptation \& psychometric validation of research instruments: A methodological review. Journal of Behavioral Health, 5(3), 129-136.

Barry, H. (1969). Cross-cultural research with matched pairs of societies. Journal of Social Psychology, 79(1), 25-33.

Beaton, D. E., Bombardier, C., Guillemin, F. \& Ferraz, M. B. (2002) Recommendations for the cross-cultural adaptation of health status measures. Available at: http://www.dash.iwh.on.ca/assets/images/pdfs/xculture2002.pdf

Beaton, D. E., Bombardier, C., Guillemin, F., \& Ferraz, M. B. (2000). Guidelines for the process of cross-cultural adaptation of self-report measures. Spine, 25(24), 3186-3191.

Bhalla, G., \& Lin, L. (1987), Cross-cultural marketing research: a discussion of equivalence issues and measurement strategies. Psychology and Marketing, 4(4), 275-285.

Bonomi, A. E., Cella, D. F., Hahn, E. A., et al. (1996). Multilingual translation of the Functional Assessment of Cancer Therapy (FACT) quality of life measurement system. Qual Life Research, 5(3), 309-320.

Brislin R.W. (1970) Back-translation for cross-cultural research. Journal of Cross-cultural Psychology, 1(3), 185-216.

Caminiti, C., Diodati, F., Filiberti, S., Marcomini, B., Annunziata, M. A., Ollari, M., et al. (2010). Cross-cultural adaptation and patients' judgments of a Question Prompt List for Italian-speaking cancer patients. BMC Health Services Research, 10(16), 1-8.

Cantarero, K., Van Tilburg, W. A., Kuźma, B., Gąsiorowska, A., \& Wojciszke, B. (2019). Some People Probably Need to Make More Sense: An Exploratory Study on Individual Differences and the Need for Sense-Making. Polish Psychological Bulletin, 50(2), 114-118.

Carr, S., Gilbride, N., \& James, C. (2017). School principals: Their adult ego development stage, their sense-making capabilities and how others experience them. SchoolLeadership \& Management,1-19.

Cerulo, K. A. (2018). Scents and sensibility: olfaction, sense-making, and meaning attribution. American Sociological Review, 83(2), 361-389.

Chen, H. Y., \& Boore, J. R. (2009). Translation and back- translation in qualitative nursing research: methodological review. Journal of clinical nursing, 19(1- 2), 234-239.

Comrey, A., \& Lee, H. (1992). A First Course in Factor Analysis (2nd edn.) Lawrence Earlbaum Associates Publishers: Hillsdale, New Jersey.

Cooper, D. J., Ezzamel, M., \& Robson, K. (2019). The Multiplicity of Performance Management Systems: Heterogeneity in Multinational Corporations and Management Sense- Making. Contemporary Accounting Research, 36(1), 451-485.

Cruz, F. A. D., Padilla, G. V. \& Agustin, E. O. (2000). Adapting a measure of acculturation for cross-cultural research. Journal of Transcultural Nursing, 11, 191-198. 
Da Mota Falcao, D., Ciconelli, R. M., \& Ferraz, M. B. (2003). Translation and cultural adaptation of quality of life questionnaires: an evaluation of methodology. $J$ Rheumatol, 30(2), 379-385.

Devellis, R. F. (2012). Scale development theory and applications (Third Edition), London: SAGE Publications, Inc.

Dougherty, D. S., \& Drumheller, K. (2006). Sensemaking and emotions in organizations: Accounting for emotions in a rational(ized) context. Communication Studies, 57(2), 215-238.

Dyer, R. (2017). Cultural sense-making integration into risk mitigation strategies towards megaproject success. International journal of project management, 35(7), 1338-1349.

Emhan, A., Mete, M., \& Emhan, A. (2012). Kamu ve özel sektör çalışanlarında işkoliklik ve obsesyon arasındaki ilişkinin incelenmesi. Dicle Tip Dergisi, 39(1), 75-79.

Epstein, J., Osborne, R. H., Elsworth, G. R., Beaton, D. E., \& Guillemin, F. (2015). Crosscultural adaptation of the Health Education Impact Questionnaire: experimental study showed expert committee, not back-translation, added value. Journal of clinical epidemiology, 68(4), 360-369.

Epstein, J., Santo, R. M., \& Guillemin, F. (2015). A review of guidelines for cross-cultural adaptation of questionnaires could not bring out a consensus. Journal of clinical epidemiology, 68(4), 435-441.

Esposito, N. (2001). From meaning to meaning: the influence of translation techniques on non-English focus group research. Qualitative Health research, 11(4), 568-579.

Fidell, L. S., \& Tabachnick, B. G. (2014). Using multivariate statistics (New International Edition ed.). Pearson: California.

Foldy, E., Goldman, G. L. \& Ospina, S. (2008). Sensegiving and the role of cognitive shifts in the work of leadership, The Leadership Quarterly, 19(5), 514-529.

Goncalves, R. S., Cabri, J., Pinheiro, J. P., Ferreira, P. L., \& Gil, J. (2010). Cross-cultural adaptation and validation of the Portuguese version of the intermittent and constant osteoarthritis pain (ICOAP) measure for the knee. Osteoarthritis Cartilage, 18, 10581061 .

Gross, M. K. (2010). Sense-making in theory and practice: a metatheoretical foundation and application for health information seeking. MSc Thesis, University of Illinois at Urbana, Illinois, 1-49.

Guillemin, F., Bombardier, C., \& Beaton, D. (1993). Cross-cultural adaptation of healthrelated quality of life measures: literature review and proposed guidelines. Journal of clinical epidemiology 46(12), 1417-1432.

Hagell, P., Per-Johan, H., Meads, D. M., Nyberg, L., \& McKenna, S. P. (2010). Effects of Method of Translation of Patient-Reported Health Outcome Questionnaires: A Randomized Study of the Translation of the Rheumatoid Arthritis Quality of Life (RAQoL) Instrument for Sweden. International Society for Pharmacoeconomics and Outcomes Research (ISPOR) 13(4), 424-430

Hahn, K. T., Emigh, P. J., Lenz, M., \& Gire, E. (2017). Student sense-making on homework in a sophomore mechanics course. PERC Proceedings, 26-27.

Haverly, C., Calabrese B., A., Schwarz, C. V., \& Braaten, M. (2020). Making Space: How Novice Teachers Create Opportunities for Equitable Sense-Making in Elementary Science. Journal of Teacher Education, 71(1), 63-79.

Henneberg, S. C., Naudé, P., \& Mouzas, S. (2010). Sense-making and management in business networks-Some observations, considerations, and a research agenda. Industrial Marketing Management, 39(3), 355-360. 
Hermann, M. G., \& Dayton, B. W. (2008). Transboundary Crises through the Eyes of Policymakers: Sense Making and Crisis Management. 'Surviving Future Disasters' Conference Sponsored by the Stephenson Disaster Management Institute at Louisiana State University, New York, USA.

http://www.tdk.gov.tr 27.04.2019.

Hughes, N. D., Locock, L., Simkin, S., Stewart, A., Ferrey, A. E., Gunnell, D., ... \& Hawton, K. (2017). Making sense of an unknown terrain: how parents understand self-harm in young people. Qualitative health research, 27(2), 215-225.

Ito, K., \& Inohara, T. (2015). A model of sense-making process for adapting new organizational settings; Based on case study of executive leaders in work transitions. Procedia-Social and Behavioral Sciences, 172, 142-149.

Jakobsen, M., Worm, V., \& Li, X. (2018). Making Sense of Context in International Business: Some Methodological Reflections. Asia Pacific Management Review, 23(4), 251-257.

Karagöz, Y. (2016). SPSS ve AMOS 23 uygulamall istatistiksel analizler. Ankara: Nobel Yayınc1lik.

Keiichiro, H. (2001). Translation and 'true language'. Publishing Research Quarterly, 17(1), 53-54.

Kharchenkova, S. (2018). The market metaphors: Making sense of the emerging market for contemporary art in China. Poetics, 71, 71-82.

Lammers, C. J., \& Hickson, D. J. (1979). Are Organizations Culture-bound? In Organizations Alike and Unlike. (ed. C. J. Lammers and D. J. Hickson). London: Routledge \& Kegan Paul Ltd.

Laurent, A. (1980). Matrix Organizations and Latin Cultures: A Note on the Use of Comparative Research. International Studies of Management and Organization, 10(4), 101-114.

Leite, P., Rangé, B., Kukar-Kiney, M., Ridgway, N., Monroe, K., Ribas J. R., et al. (2013). Cross-cultural adaptation, validation and reliability of the Brazilian version of the Richmond Compulsive Buying Scale. Brazilian Journal of Psychiatry, 35(1), 38-43.

MacCallum, R. C., Widaman, K. F., Zhang, S., \& Hong, S. (1999). Sample size in factor analysis. Psychological methods, 4(1), 84-99.

Maitlis, S., \& Christianson, M. (2014). Sensemaking in organizations: Taking stock and moving forward. The academy of management annuals, 8(1), 57-125.

Malhotra, N. K., Agarwal, J., Peterson, M. (1996). Methodological issues in cross-cultural marketing research. International Marketing Review, 13(5), 7-43.

Maneesriwongul, W. \& Dixon, J. K. (2004) Instrument translation process: a method review. Journal of Advanced Nursing, 48(2), 175-185.

Mattsson, L. G., Corsaro, D., Ramos, C. (2015). Sense-making in business markets-the interplay between cognition, action and outcomes. Industrial Marketing Management, 48, 4-11.

Mokkink, L. B., Terwee, C. B., Patrick, D. L., Alonso J., Stratford P. W., Knol D. L., et al. (2010). The COSMIN study reached international consensus on taxonomy, terminology, and definitions of measurement properties for health-related patientreported outcomes. J Clin Epidemiol, 63(7), 737-745.

Munet-Vilar'o, F. \& Egan, M. (1990). Reliability issues of the family environment scale for cross-cultural research. Nursing Research, 39(4), 244-247.

Müller, S., Kohlmann, T., Wilke, T. (2015). Validation of the adherence barriers questionnaire - An instrument for identifying potential risk factors associated with medication-related non-adherence. BMC Health Serv Res, 15, 1-12. 
Nasif, E. G., Al-Daeaj, H., Ebrahimi, B., \& Thibodeaux, M. S. (1991). Methodological problems in cross-cultural research: An updated review. MIR: Management International Review, 31(1), 79-91.

Nath, R. (1968). A Methodological Review of Cross-Cultural Management Review. International Social Science Journal, 20, 35-62.

Nunnally, J. C., \& Bernstein, I. H. (1994). Psychometric Theory (3rd ed.). New York: McGraw-Hill, Inc..

Ola, B. A., \& Igbokwe, D. O. (2011). Factorial validation and reliability analysis of the Brain Fag Syndrome Scale. African Health Sciences, 11(3), 334-40.

Ortiz-Gutiérrez, S., \& Cruz-Avelar, A. (2018). Translation and Cross-Cultural Adaptation of Health Assessment Tools. Actas dermo-sifiliograficas, 109(3), 202-206.

Örün, Ö., Orhan, D., Dönmez, P., \& Kurt, A. A. (2015). Öğretmen adaylarının bireysel yenilikçilik profilleri ve teknoloji tutum düzeyleri arasındaki ilişkinin incelenmesi. Trakya Üniversitesi Eğitim Fakültesi Dergisi, 5(1), 65-76.

Pakenham, K. I. (2007). Making sense of multiple sclerosis. Rehabilitation Psychology, 52(4), 380-389. https://doi.org/10.1037/0090-5550.52.4.380

Parameswaran, R., \& Yaprak, A. (1987). A cross-national comparison of consumer research measures. Journal of International Business Studies, 18(1), 35-49.

Parsian, N., \& Dunning, A. M. (2009). Developing and validating a questionnaire to measure spirituality: A psychometric process. Global Journal of Health Science, 1(1), 1-11.

Paula, H. R., Haddad, A., Weiss, M. A., Dini, G. M., \& Ferreira, L. M. (2014). Translation, cultural adaptation, and validation of the American Skindex-29 quality of life index. An Bras Dermatol, 89(4), 600-607.

Perneger, T. V., Leplege, A, Etter, J. F. (1999). Cross-cultural adaptation of a psychometric instrument: two methods compared. J Clin Epidemiol, 52(11), 1037-1046.

Riva, S., Gorini, A., Cutica, I., Mazzocco, K., \& Pravettoni, G. (2015). Translation, crosscultural adaptation, and reliability, of the Italian version of the Passive Risk Taking (PRT) scale. Judgment and Decision Making, 10(6), 597-604.

Santos, J. J., Costa, T. A., Guilherme, J. H., Silva, W. C., Abentroth, L. R., Krebs, J. A., et al. (2015). Adaptation and cross-cultural validation of the Brazilian version of the Warwick-Edinburgh mental well-being scale. Revista da Associação Médica Brasileira, 61(3), 209-214.

Saris-Baglama, R. N., Dewey, C. J., Chisholm, G. B., et al. (2004). SF Health Outcomes ${ }^{\mathrm{TM}}$ Scoring Software User's Guide. Lincoln: Quality-Metric, Inc..

Schiavio, A., \& De Jaegher, H. (2017). Participatory sense-making in joint musical practice. In The Routledge companion to embodied music interaction (pp. 31-39). Routledge.

Sekaran, U. (1983). Methodological and Theoretical Issues and Advancements in CrossCultural Research. Journal of International Business Studies, 14, 61-73.

Smerek, R. E. (2009). Sensemaking and Sensegiving: Leadership Processes of New College Presidents. Doctor of Philosophy in The University of Michigan.

Sousa, V. D., \& Rojjanasrirat, W. (2011). Translation, adaptation and validation of instruments or scales for use in cross- cultural health care research: a clear and userfriendly guideline. Journal of evaluation in clinical practice, 17(2), 268-274.

Sousa, V. D., Zauszniewski, J. A., Mendes, I. A. C. \& Zanetti, M. L. (2005). Cross-cultural equivalence and psychometric properties of the Portuguese version of the depressive cognition scale. Journal of Nursing Measurement, 13(2), 87-99.

Stieglitz, S., Bunker, D., Mirbabaie, M., \& Ehnis, C. (2017). Sense- making in social media during extreme events. Journal of Contingencies and Crisis Management, 26(1), 4-15.

Tillmann, K., \& Goddard, A. (2008). Strategic management accounting and sense-making in a multinational company. Management accounting research,19(1), 80-102. 
Trousselard, M., Steiler, D., Raphel, C., Cian, C., Duymedjian, R., Claverie, D., et al. (2010). Validation of a French version of the Freiburg Mindfulness Inventory - Short version: Relationships between mindfulness and stress in an adult population. BioPsychoSocial Medicine, 4(1), 1-11.

Tuğsal, T. (2015). Finansal Krizler ve Anlamlandırma Teorisi: 2008 Krizine Retrospektif Bir Yaklaşım. Siyaset, ekonomi ve yönetim araştırmaları dergisi, 2(2), 111-124.

Tuğsal, T. (2016). İş Yaşamında Duyguları Anlamlandırmanın Örgütlere ve Çalışanlara Faydaları (Örgüt Yönetiminde Duygular, ed. Ülgen, B.), 69-90, Ankara: Nobel Yayıncilik.

Tuğsal, T. (2018). İş-Yaşam Dengesi, Sosyal Destek ve Sosyo-Demografik Faktörlerin Tükenmişlik Üzerindeki Etkisi. İstanbul: Cinius Yayınları.

Tuğsal, T. (2019). Anlamlandırma Teorisi ve Anlamlandırma Ölçeği Geliştirme Çalışması: Bireylerin Çevrelerindeki Davranışları, Olayları, İşaretleri ve Farklılıkları Anlamlandırma Durumları. Bingöl Üniversitesi Sosyal Bilimler Enstitüsü Dergisi, 9(17), 483-492.

Twinn, S. (1998). An analysis of the effectiveness of focus groups as a method of qualitative data collection with Chinese populations in nursing research. Journal of Advanced Nursing 28(3), 654-661.

Weick, K. (1988). Enacted sensemaking in crisis situations. Journal of management studies, 25(4), 305-317.

Weinberg, A., Wiesner, E., \& Fukawa-Connelly, T. (2014). Students' sense-making frames in mathematics lectures. The Journal of Mathematical Behavior, 33, 168-179.

Wild, D., Grove, A., Martin, M., et al. (2005). Principles of good practice for the translation and cultural adaptation Process for Patient-Reported Outcomes (PRO) measures: report of the ISPOR task force for translation and cultural adaptation. Value Health, 8(2), 94-104.

Williams, B., Onsman, A., \& Brown, T. (2010). Exploratory factor analysis: A fivestep guide for novices. Aust J Paramed, 8, 1-13.

$\mathrm{Wu}, \mathrm{S} . \mathrm{F}$. (2006). Two stage translation and test the validity and reliability of a foreign instrument. The Journal of Nursing, 53(1), 65-71.

$\mathrm{Xu}$, S. (2018). Crisis communication within a community: Bonding, coping, and making sense together. Public Relations Review, 44(1), 84-97.

$\mathrm{Yu}$, J.H., Keown, C.F. \& Jacobs, L.W. (1993). Attitude scale methodology: cross-cultural implications. Journal of International Consumer Marketing, 6(2), 45-64.

Yurdugül, H. (2005). Ölçek Geliştirme Çalışmalarında Kapsam Geçerliği için Kapsam Geçerlik Endekslerinin Kullanılması. XIV. Ulusal Eğitim Bilimleri Kongresi Pamukkale Üniversitesi Eğitim Fakültesi 28-30 Eylül 2005 Denizli. 


\section{Appendix}

\section{The Sense-Making Scale (S-MS) English Version}

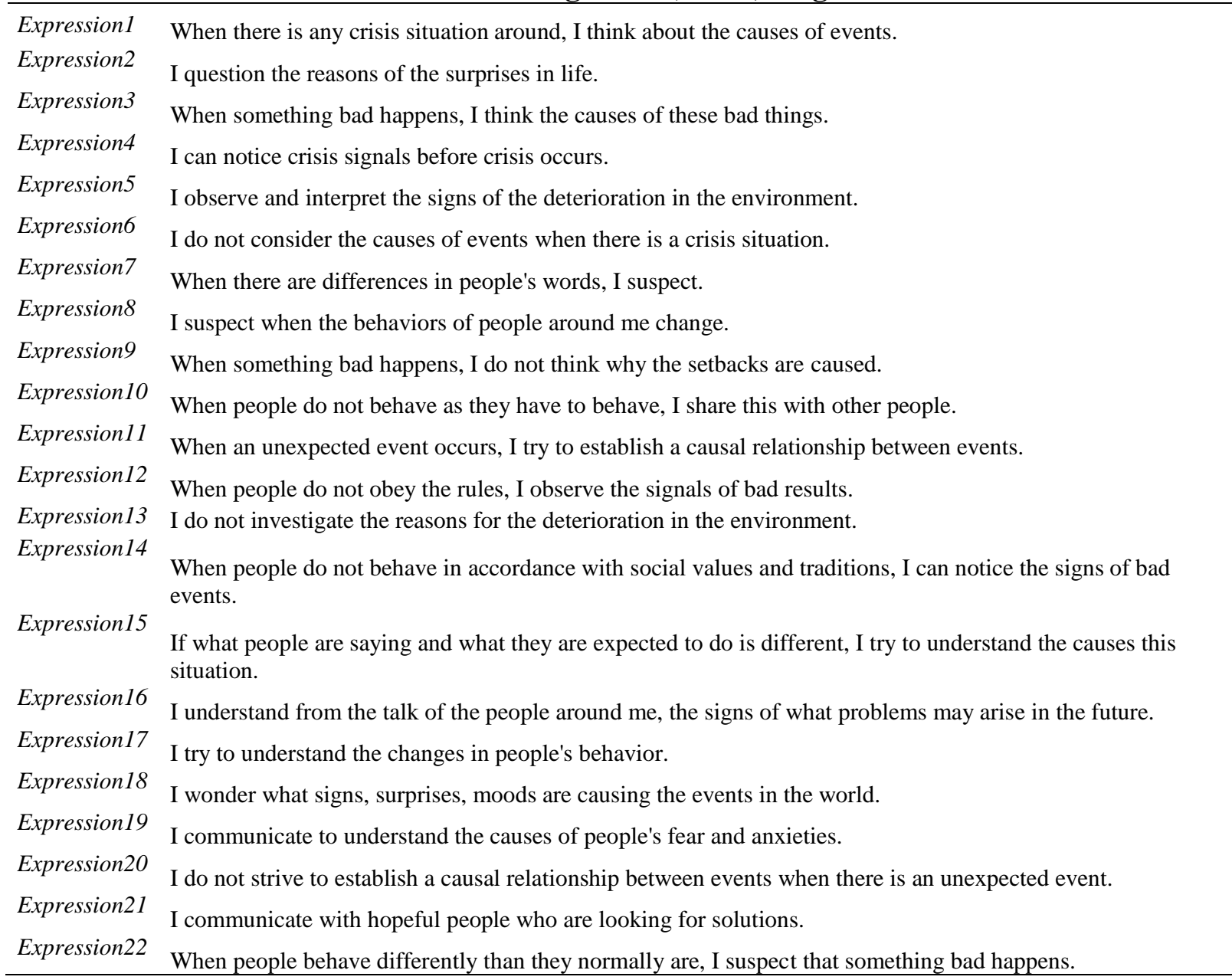

